\title{
Study on the risk and impacts of land subsidence in Jakarta
}

\author{
H. Z. Abidin ${ }^{1}$, H. Andreas ${ }^{1}$, I. Gumilar ${ }^{1}$, and J. J. Brinkman ${ }^{2}$ \\ ${ }^{1}$ Geodesy Research Group, Faculty of Earth Science and Technology, Institute of Technology Bandung, \\ Bandung 40132, Indonesia \\ ${ }^{2}$ Deltares, Delft, Netherlands \\ Correspondence to: H. Z. Abidin (hzabidin@gmail.com)
}

Published: 12 November 2015

\begin{abstract}
Jakarta is the capital city of Indonesia located in the west-northern coast of Java island, within a deltaic plain and passes by 13 natural and artificial rivers. This megapolitan has a population of about 10.2 million people inhabiting an area of about $660 \mathrm{~km}^{2}$, with relatively rapid urban development. It has been reported for many years that several places in Jakarta are subsiding at different rates. The main causative factors of land subsidence in Jakarta are most probably excessive groundwater extraction, load of constructions (i.e., settlement of high compressibility soil), and natural consolidation of alluvial soil. Land subsidence in Jakarta has been studied using leveling surveys, GPS surveys, InSAR and Geometric-Historic techniques. The results obtained from leveling surveys, GPS surveys and InSAR technique over the period between 1974 and 2010 show that land subsidence in Jakarta has spatial and temporal variations with typical rates of about 3-10 $\mathrm{cm}_{\text {year }}{ }^{-1}$. Rapid urban development, relatively young alluvium soil, and relatively weak mitigation and adapatation initiatives, are risk increasing factors of land subsidence in Jakarta. The subsidence impacts can be seen already in the field in forms of cracking and damage of housing, buildings and infrastructure; wider expansion of (riverine and coastal) flooding areas, malfunction of drainage system, changes in river canal and drain flow systems and increased inland sea water intrusion. These impacts can be categorized into infrastructural, environmental, economic and social impacts. The risk and impacts of land subsidence in Jakarta and their related aspects are discussed in this paper.
\end{abstract}

\section{Introduction}

Land subsidence is a natural-anthropogenic hazard affecting quite many large urban areas (cities) in the world, including Jakarta, the capital city in Indonesia. It is located on the lowland area in the northern coast of West Java, centered at the coordinates of about $6^{\circ} 15^{\prime} \mathrm{S}$ and $+106^{\circ} 50^{\prime} \mathrm{E}$ (see Fig. 1), within a deltaic plain and passes by 13 natural and two canals. This megapolitan has a population of about 10.1 million people in 2014, inhabiting an area of about $662 \mathrm{~km}^{2}$, with relatively rapid urban development. Topographically, the area of Jakarta has slopes ranging between 0 and $2^{\circ}$ in the northern and central parts, between 0 and $5^{\circ}$ in the southern part, and its southern-most area has an altitude of about $50 \mathrm{~m}$ above mean sea level.
Land subsidence is a well known phenomena affecting Jakarta, and it has been observed using several geodetic techniques and has been widely reported for many years (Rismianto and Mak, 1993; Murdohardono and Sudarsono, 1998; Purnomo et al., 1999; Rajiyowiryono, 1999; Abidin et al., 2001, 2004, 2008, 2010, 2011, 2013; Koudogbo et al., 2012; Ng et al., 2012; Chaussard et al., 2013). According to those studies, land subsidence in Jakarta has spatial and temporal variations with typical rates of about 3$10 \mathrm{~cm}_{\text {year }}{ }^{-1}$.

Land subsidence impacts in Jakarta can be seen already in the field in forms of cracking and damage of housing, buildings and infrastructure; wider expansion of (riverine and coastal) flooding areas, malfunction of drainage system, changes in river canal and drain flow systems and in- 


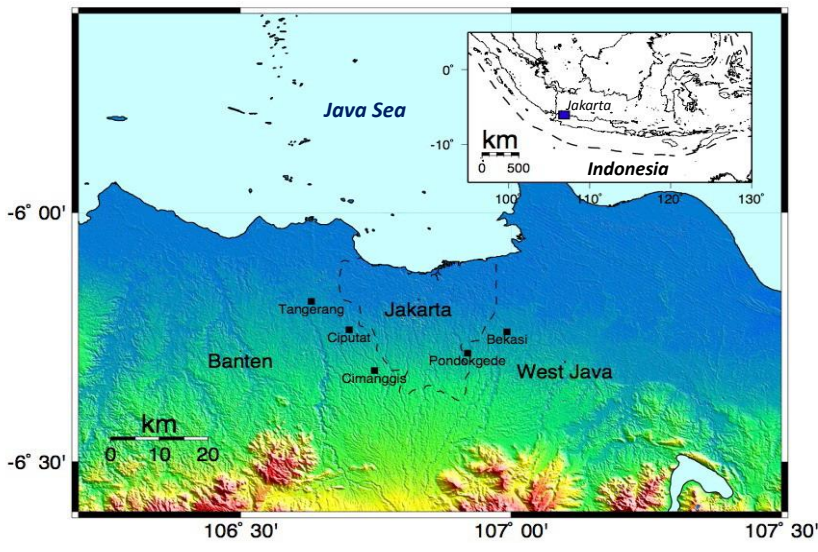

Figure 1. Location of Jakarta, the capital city of Indonesia.

\begin{tabular}{|c|c|}
\hline \multicolumn{1}{|c|}{ LAND SUBSIDENCE INFORMATION } \\
(Magnitudes, Rates, Spatial \& Temporal Variations)
\end{tabular}

Figure 2. Importance of land subsidence information for urban development.

creased inland sea water intrusion. In general, these impacts can be categorized into infrastructural, environmental, economic and social impacts.

Since information of land subsidence characteristics is important for sustainable urban development of Jakarta (see Fig. 2), then understanding the risk and impacts of land subsidence in Jakarta and their related aspects is very important and strategic, and land subsidence charactristics should be continuously monitored.

\section{Land subsidence characteristics in Jakarta}

Land subsidence phenomena in Jakarta has actually been observed using several geodetic methods, such as Leveling survey, GPS survey, InSAR, Microgravity survey, and Geometric-Historic method. In general, the observed land subsidence in Jakarta has spatial and temporal variations, with the typical rates of about $3-10 \mathrm{~cm} \mathrm{year}^{-1}$ (see Figs. 3,4$)$. These subsidence rates are obtained from the in-

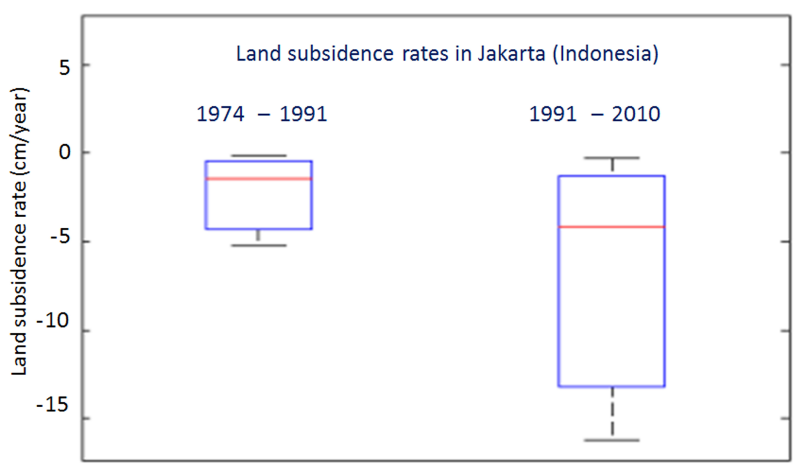

Figure 3. Box plots of land subsidence rates in Jakarta during the period of 1974-1991 (left) and 1991-2010 (right). Subsidence rate unit is $\mathrm{cm}^{-1}$ year $^{-1}$.
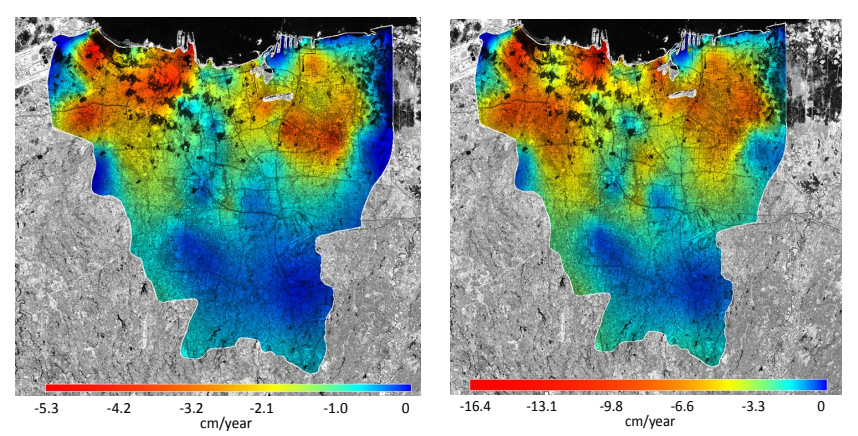

Figure 4. Rates of land subsidence in Jakarta during the period of 1974-1991 (left) and 1991-2010 (right); courtesy of Irwan Gumilar of Geodesy Research Group of ITB.

tegration of results obtained by the Leveling surveys (19741997), GPS surveys (1997-2010), and InSAR technique (2006-2010). In this period of about 37 years (1974-2010), the total subsidence of up to about $4 \mathrm{~m}$ have been observed in several locations in Jakarta. The observed land subsidences along the coastal areas of Jakarta are relatively have larger rates than the inland areas. Figures 3 and 4 also show the existence of spatial variation in subsidence rates along the coastal zone of Jakarta, in which the central and western parts have relatively larger rates. These larger rates of subsidence are mainly due to higher volumes of groundwater extraction, combined with relatively younger alluvium soil composition. More information on land subsidence characteristics in Jakarta can be seen in Abidin et al. (2001, 2004, 2008, 2010, 2011, 2013, 2014, 2015a, b), Ng et al. (2012), Chaussard et al. (2013).

The studies from Murdohardono and Sudarsono (1998), Rismianto and Mak (1993), Harsolumakso (2001), and Hutasoit (2001) suggested that the possible causative factors of land subsidence in Jakarta are most probably: excessive groundwater extraction, load of constructions (i.e., settlement of high compressibility soil), natural consolidation of alluvial soil, and tectonic activities. Land subsidence in cer- 
tain area is usually caused by combination of those factors. Considering the spatial variation of land subsidence rates in Jakarta area, then it can be expected that the contribution of each factor on land subsidence at each location also will has spatial variation. In Jakarta, tectonic activities seem to be the least dominant factor, while excessive groundwater extraction is considered to be one of dominant factor for causing land subsidence.

\section{Land subsidence risk in Jakarta}

Considering the aforementioned causative factors of land subsidence in Jakarta, actually there are three main risk increasing factors of land subsidence in Jakarta that can be considered, namely: relatively young alluvium soil in which Jakarta is located, rapid urban development, and relatively weak imposement of land subsidence mitigation and adaptation measures (see Fig. 5).

Jakarta is located in a lowland coastal areas, composed by relatively young and soft alluvium soil. According to Rimbaman and Suparan (1999), there are five main landforms of Jakarta, namely: alluvial landforms (southern part), landforms of marine-origin (northern part adjacent to the coastline), beach ridge landforms (northwest and northeast parts), swamp and mangrove swamp landforms (coastal fringe), and former channels (perpendicular to the coastline). There are also 13 rivers and 2 canals flowing across Jakarta from its southern part and have estuaries in Java sea along an approximately $35 \mathrm{~km}$ of coastline. Jakarta basin, according to Yong et al. (1995), its consisted of a 200-300 m thick sequence of quaternary deposits which overlies tertiary sediments, in which the top sequence is thought to be the base of the groundwater basin. The quaternary sequence itself can be further subdivided into three major units, which, in ascending order are: a sequence of pleistocene marine and nonmarine sediments, a late pleistocene volcanic fan deposit, and holocene marine and floodplain deposits.

The above geological and geomorphological conditions make Jakarta has a higher risk (prone) toward land subsidence phenomena, especially in cases of excessive groundwater extraction and massive loading from buildings and infrastructures.

Rapid urban development in Jakarta also contributes to increasing risk of land subsidence occurences in Jakarta (Abidin et al., 2011). In this case, the increases in built-up areas, population, economic and industrial activities, will then increase groundwater extraction and also buildings and infrastructure loadings; which usually in turn lead to land subsidence phenomena. The relatively very rapid urban development of Jakarta as a megapolitan city is mainly in the sectors of industry, trade, transportation, housing, hotel and apartment, and many others (Firman, 1999, 2004; Hudalah et al., 2013); and they have introduced several negative environmental problems (Firman and Dharmapatni, 1994; Hu-

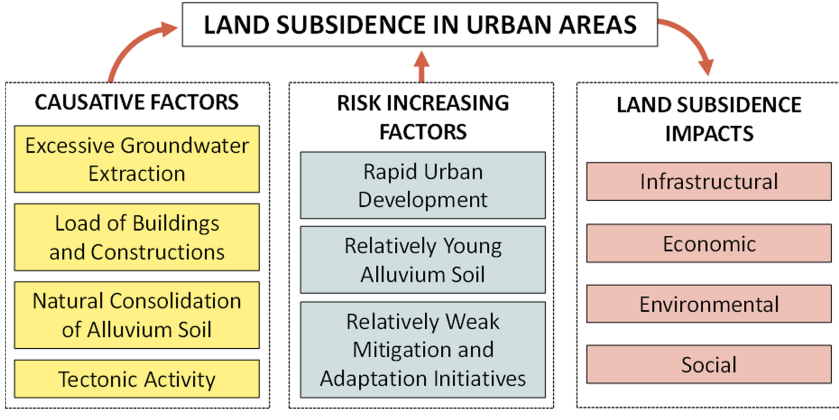

Figure 5. The causative factors, risk increasing factors and impacts of land subsidence in urban areas of Indonesia.

dalah and Firman, 2012), such as: extensive conversion of agricultural areas into residential and industrial areas, significant disturbance to ecological and hydrological functions of the upland of Jakarta area and river catchment areas, and increase in groundwater extraction due to development of industrial activities and the high population increase. Coastal area of Jakarta which is mainly composed by relatively young and soft alluvium soil, has also experienced extensive urban development, such as establishment of sea port, coastal resort, golf course, residential areas, industries, apartments, malls, hotels, and commercials and office buildings. Coastal reclamation has also been conducted to accomodate more coastal development initiatives. These extensive urban development activities will have contribution into increasing land subsidence risk in several places in Jakarta (Abidin et al., 2011).

The other risk increasing factor of land subsidence in Jakarta is a relatively weak mitigation and adaptation initiatives (see Table 1) being implemented in Jakarta. At present, land subsidence hazard is not yet properly considered in urban development and spatial planning, groundwater extraction regulation system, and building codes in Jakarta. Although the regulation has been introduced to limit groundwater extraction in several subsidence prone areas in Jakarta; however, its enforcement is still need to be proven.

\section{Land subsidence impacts in Jakarta}

In general, the impacts of land subsidence in Jakarta can be seen in the field in various forms as shown in Fig. 6, such as cracking of permanent constructions and roads, tilting of houses and buildings, "sinking" of houses and buildings, changes in river canal and drain flow systems, wider expansion of coastal and/or inland flooding areas, and increased inland sea water intrusion. These subsidence impacts can be categorized into infrastructure, environmental, economic, and social impacts (see Table 2). Most of these impacts are indirectly generated due to land subsidence in the areas, and several of them are directly caused by subsidence. More over, these subsidence impacts have also rela- 
Table 1. Examples of mitigation and adaptation initiatives for decreasing land subsidence risk in urban areas.

\begin{tabular}{|c|c|c|}
\hline Causative factors & Mitigation & Adaptation \\
\hline $\begin{array}{l}\text { Excessive } \\
\text { groundwater } \\
\text { extraction }\end{array}$ & $\begin{array}{l}\text { - Limit or prohibit groundwater } \\
\text { extraction in subsidence prone areas. } \\
\text { - Enforcement of strict regulation and } \\
\text { punishment for groundwater extraction } \\
\text { in subsidence prone areas. }\end{array}$ & $\begin{array}{l}\text { - Increase the surface groundwater supply and resources. } \\
\text { - Continuous monitoring of subsidence characteristics. }\end{array}$ \\
\hline $\begin{array}{l}\text { Load of } \\
\text { buildings and } \\
\text { infrastructures }\end{array}$ & $\begin{array}{l}\text { - Urban development planning takes into account } \\
\text { the land subsidence characteristics in the areas. } \\
\text { - Urban development rate in subsidence } \\
\text { prone areas is properly controlled. }\end{array}$ & $\begin{array}{l}\text { - Implementation of special building codes for land } \\
\text { subsidence prone areas. } \\
\text { - Continuous monitoring of subsidence characteristics. }\end{array}$ \\
\hline $\begin{array}{l}\text { Natural } \\
\text { consolidatium } \\
\text { of alluvium soil }\end{array}$ & None & $\begin{array}{l}\text { - Implementation of subsidence-adaptive } \\
\text { urban developmen and spatial planning. }\end{array}$ \\
\hline Tectonic activities & & - Continuous monitoring of subsidence characteristics. \\
\hline
\end{tabular}

Table 2. Characteristics of land subsidence impacts; after Abidin et al. (2015c).

\begin{tabular}{|c|c|c|c|}
\hline No. & Category & Representation of impact & Level of impact \\
\hline 1. & Infrastructural & $\begin{array}{l}\text { cracking of permanent constructions and roads } \\
\text { tilting of houses and buildings } \\
\text { "sinking" of houses and buildings } \\
\text { breaking of underground pipelines and utilities } \\
\text { malfunction of sewerage and drainage system } \\
\text { deterioration in function of building and infrastructures }\end{array}$ & $\begin{array}{l}\text { direct } \\
\text { direct } \\
\text { direct } \\
\text { direct } \\
\text { indirect } \\
\text { indirect }\end{array}$ \\
\hline 2. & Environmental & $\begin{array}{l}\text { changes in river canal and drain flow systems } \\
\text { frequent coastal flooding } \\
\text { wider expansion of flooding areas } \\
\text { inundated areas and infrastructures } \\
\text { increased inland sea water intrusion } \\
\text { deterioration in quality of environmental condition }\end{array}$ & indirect \\
\hline 3. & Economic & $\begin{array}{l}\text { increase in maintenance cost of infrastructure } \\
\text { decrease in land and property values } \\
\text { abandoned buildings and facilities } \\
\text { disruption to economic activities }\end{array}$ & indirect \\
\hline 4. & Social & $\begin{array}{l}\text { deterioration in quality of living environment and life } \\
\text { (e.g. health and sanitation condition) } \\
\text { disruprion to daily activities of people }\end{array}$ & indirect \\
\hline
\end{tabular}

tion among each other, and its connection system is simplified by Fig. 7.

The potential losses due to land subsidence in urban areas such as Jakarta are actually quite significant (Ward et al., 2011; Viets, 2010). Related infrastructural, social and environmental costs due to direct and indirect impacts of land subsidence are economically quite significant, and can not be under estimated in sustainable urban development. In this regard for example, the planning, development and maintenance costs of building and infrastructures in the affected areas are usually much higher than the normal situation. The collateral impact of coastal subsidence in Jakarta, in the form of coastal flooding during high tides is also quite damaging (Abidin et al., 2011, 2015b). This repeated coastal flooding in several areas along the coast, will deteriorates the structure and function of building and infrastructures, badly influences the quality of living environment and life (e.g. health and sanitation condition), and also disrupts economic and social activities in the affected areas. Inland subsidence should also has an impact on inland flooding phenomena in Jakarta (Texier, 2008), since it will theoretically lead to expanded coverage and deeper water depth of flooded (inundated) areas 

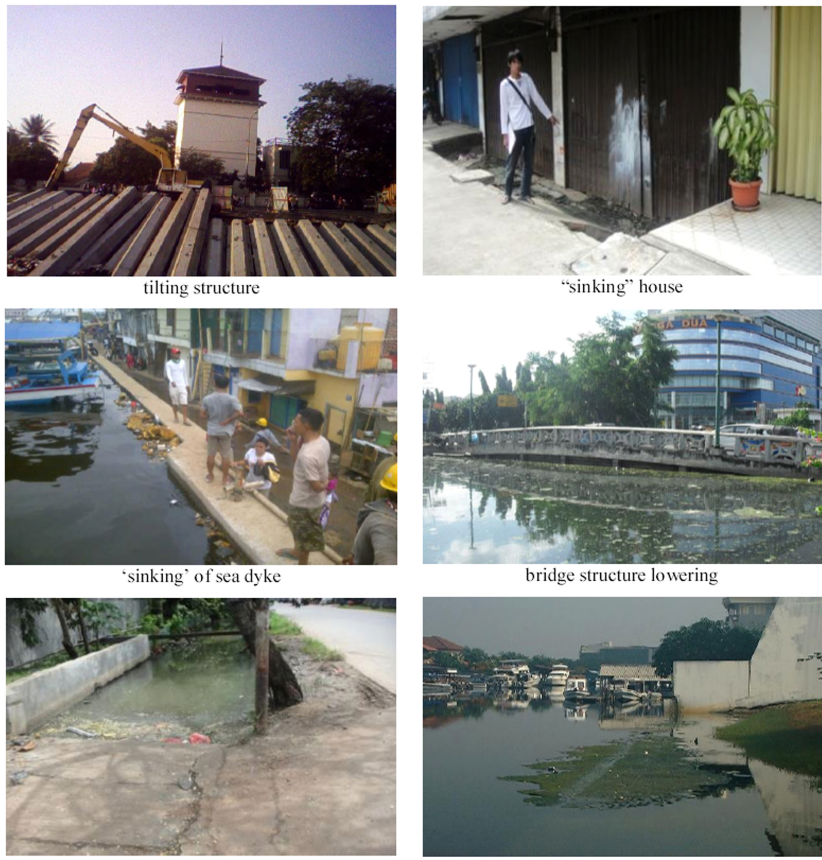

malfunction of drainage

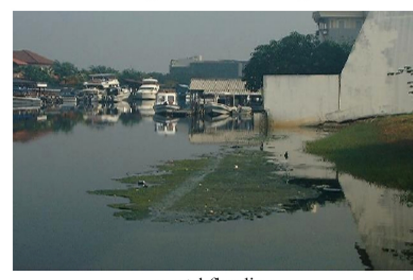

coastal flooding

Figure 6. Examples of representation in the field of land subsidence impacts in Jakarta.

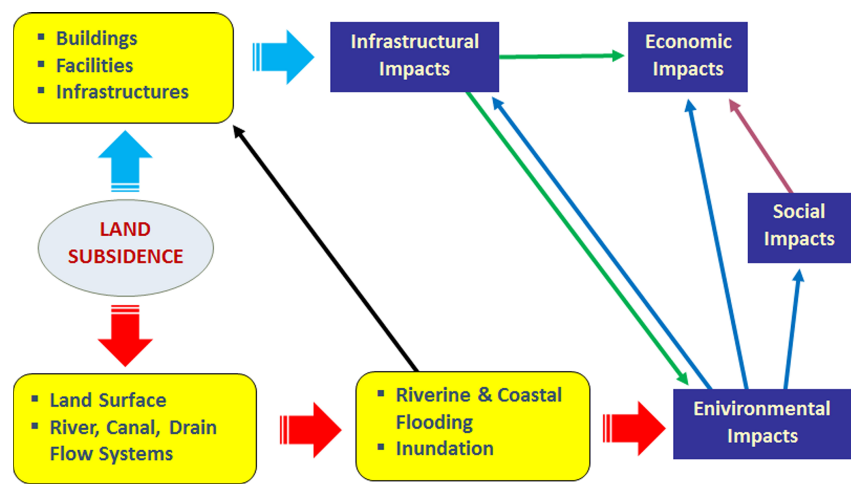

Figure 7. Land subsidence impacts in urban areas and its connection system, from Abidin et al. (2015c).

(Abidin et al., 2015b, c). The losses due to inland flooding in Jakarta are also significant since it affects many economic related activities in the city and surrounding regions.

\section{Closing remarks}

Land subsidence is a natural-anthropogenic hazard affecting Jakarta, with typical rates of about $3-10 \mathrm{~cm}$ year $^{-1}$. Its direct and indirect impacts can be easily seen nowadays in the field. Without good and effective mitigation and adaptation initiatives, land subsidence hazard in Jakarta can have more disastrous impacts in the future. In this case, the infrastructural, economic, environmental and social impacts of land subsidence can be quite a heavy burden for sustainable development of Jakarta.

At present, detail characteristics and mechanisms of land subsidence in Jakarta, both in spatial and temporal domains, are still not yet fully established. Contribution of each causative factors on observed land subsidence in certain areas still needs to be estimated and modelled. In this regard, the implementation of continuous subsidence monitoring system (e.g. GNSS CORS system) in Jakarta is necessary. Since, there is quite a strong linkage between geological and geomorphological condition, and rapid urban development in Jakarta with land subsidence characteristics, then subsidence mitigation and adaptation initiatives should be integrated in urban development program and spatial planning of Jakarta.

Finally, it should be pointed out that based on preliminary studies (Abidien et al., 2015b), it is found that there is some spatial correlation between land subsidence affected areas with flooded (inundated) areas in Jakarta. However, since the exact relation mechanism between the two phenomena is not yet established; then more quantitative characteristics of this correlation cannot be estimated. In order to establish a quantitative relation between land subsidence and flooding phenomena in Jakarta, then the following activities should be conducted, namely: detail mapping of the spatial and temporal rates and impacts of land subsidence, detail mapping of flooded (inundated) area during the flooding events, and detail flood risk modelling for Jakarta.

Acknowledgements. Land subsidence study in Jakarta using space geodetic techniques has been conducted by the Geodesy Research group of ITB since 1997, by using several research grants from Ministry of Science, Technology, and Higher Education of Indonesia, from the Provincial Government of Jakarta, and from ITB Research programs. The GPS surveys were conducted by the Geodesy Research Group of ITB, the Geospatial Agency of Indonesia, and the staffs and students from the Department of Geodesy and Geomatics Engineering of ITB.

\section{References}

Abidin, H. Z., Djaja, R., Darmawan, D., Hadi, S., Akbar, A., Rajiyowiryono, H., Sudibyo, Y., Meilano, I., Kusuma, M. A., Kahar, J., and Subarya, C.: Land Subsidence of Jakarta (Indonesia) and its Geodetic-Based Monitoring System, Nat. Hazards, 23, 365387, doi:10.1023/A:1011144602064, 2001.

Abidin, H. Z., Djaja, R., Andreas, H., Gamal, M., Hirose, K., and Maruyama, Y.: Capabilities and Constraints of Geodetic Techniques for Monitoring Land Subsidence in the Urban Areas of Indonesia, Geomatics Research Australia, 81, 45-58, 2004.

Abidin, H. Z., Andreas, H., Djaja, R., Darmawan, D., and Gamal, M.: Land subsidence characteristics of Jakarta between 1997 and 2005, as estimated using GPS surveys, GPS Solutions, Springer Berlin/Heidelberg, 12, 23-32, 2008.

Abidin, H. Z., Andreas, H., Gamal, M., Gumilar, I., Napitupulu, M., Fukuda, Y., Deguchi, T., Maruyama, Y., and Riawan, E.: Land 
Subsidence Characteristics of the Jakarta Basin (Indonesia) and its Relation with Groundwater Extraxtion and Sea Level Rise, in: Groundwater Response to Changing Climate, IAH Selected Papers on Hydrogeology No. 16, edited by: Taniguchi, M. and Holman, I. P., CRC Press, London, Chapter 10, 113-130, 2010.

Abidin, H. Z., Andreas, H., Gumilar, I., Fukuda, Y., Pohan, Y. E., and Deguchi, T.: Land subsidence of Jakarta (Indonesia) and its relation with urban development, Nat. Hazards, 59, 1753-1771, 2011.

Abidin, H. Z., Andreas, H., Gumilar, I., Sidiq, T. P., and Fukuda, Y.: On the Roles of Geospatial Information for Risk Assessment of Land Subsidence in Urban Areas of Indonesia, in: Intelligent Systems for Crisis Management, Lecture Notes in Geoinformation and Cartography, edited by: Zlatanova, S., Peters, R., Dilo, A., and Scholten, H., Springer-Verlag Berlin Heidelberg, 277288, 2013.

Abidin, H. Z., Andreas, H., Gumilar, I., and Yuwono, B. D.: Performance of the Geometric-Historic Method for Estimating Land Subsidence in Urban Areas of Indonesia, Proceedings of the XXV FIG Congress, TS 10B Session - Earth Geodynamics and Monitoring 2, 16-21 June 2014, Kuala Lumpur, Malaysia, 2014.

Abidin, H. Z., Andreas, H., Gumilar, I., Yuwono, B. D., Murdohardono, D., and Supriyadi, S.: On integration of geodetic observation results for assessment of land subsidence hazard risk in urban areas of Indonesia, in: International Association of Geodesy Symposia Series, Springer Berlin Heidelberg, 143, 1-8, 2015 a.

Abidin, H. Z., Andreas, H., Gumilar, I., and Wibowo, I. R. R.: On correlation between urban development, land subsidence and flooding phenomena in Jakarta, Proc. IAHS, 370, 15-20, doi:10.5194/piahs-370-15-2015, 2015.

Abidin, H. Z., Andreas, H., Gumilar, I., Sidiq, T. P., and Gamal, M.: Environmental Impacts of Land Subsidence in Urban Areas of Indonesia, in: Proceedings of the FIG Working Week 2015, TS 3 - Positioning and Measurement, Sofia, Bulgaria, Paper no. 7568, 17-21 May 2015, 2015c.

Chaussard, E., Amelung, F., Abidin, H. Z., and Hong, S.-H.: Sinking cities in Indonesia: ALOS PALSAR detects rapid subsidence due to groundwater and gas extraction, Remote Sens. Environ., 128, 150-161, 2013.

Firman, T.: From Global City to City of Crisis: Jakarta Metropolitan Region Under Economic Turmoil, Habitat Int., 23, 447-466, 1999.

Firman, T.: New town development in Jakarta Metropolitan Region: a perspective of spatial segregation, Habitat Int., 28, 349-368, 2004.

Firman, T. and Dharmapatni, I. A. I.: The challenges to suistanaible development in Jakarta metropolitan region, Habitat Int., 18, 7994, 1994.

Harsolumakso, A. H.: Struktur Geologi dan Daerah Genangan, Buletin Geologi, 33, 29-45, 2001.

Hudalah, D. and Firman, T.: Beyond property: Industrial estates and post-suburban transformation in Jakarta Metropolitan Region, Cities, 29, 40-48, 2012.
Hudalah, D., Viantari, D., Firman, T., and Woltjer, J.: Industrial land development and manufacturing deconcentration in Greater Jakarta, Urban Geogr., 34, 950-971, 2013.

Hutasoit, L. M.: Kemungkinan Hubungan antara Kompaksi Alamiah Dengan Daerah Genangan Air di DKI Jakarta, Buletin Geologi, 33, 21-28, 2001.

Koudogbo, F. N., Duro, J., Arnaud, A., Bally, P., Abidin, H. Z., and Andreas, H.: Combined X- and L-band PSI analyses for assessment of land subsidence in Jakarta, Proc. SPIE, Remote Sensing for Agriculture, Ecosystems, and Hydrology XIV, 8531, 853107, doi:10.1117/12.974821, 2012.

Murdohardono, D. and Sudarsono, U.: Land subsidence monitoring system in Jakarta, Proceedings of Symposium on JapanIndonesia IDNDR Project: Volcanology, Tectonics, Flood and Sediment Hazards, 21-23 September 1998, Bandung, Indonesia, 243-256, 1998.

Ng, A. H.-M., Ge, L., Li, X., Abidin, H. Z., Andreas, H., and Zhang, K.: Mapping land subsidence in Jakarta, Indonesia using persistent scatterer interferometry (PSI) technique with ALOS PALSAR, Int. J. Appl. Earth Obs., 18, 232-242, 2012.

Purnomo, H., Murdohardono, D., and Pindratno, H.: Land Subsidence Study in Jakarta, Proceedings of Indonesian Association of Geologists, 30 November-1 December 1999, Jakarta, Volume IV: Development in Engineering, Environment, and Numerical Geology, 53-72, 1999.

Rajiyowiryono, H.: Groundwater and Landsubsidence Monitoring along the North Coastal Plain of Java Island, CCOP Newsletter, 24, 19 pp., 1999.

Rimbaman and Suparan, P.: Geomorphology, in: Coastplan Jakarta Bay Project, Coastal Environmental Geology of the Jakarta Reclamation Project and Adjacent Areas, Jakarta, Bangkok, CCOP COASTPLAN Case Study Report No. 2, 21-25, 1999.

Rismianto, D. and Mak, W.: Environmental aspects of groundwater extraction in DKI Jakarta: Changing views, Proceedings of the 22nd Annual Convention of the Indonesian Association of Geologists, 6-9 December 1993, Bandung, Indonesia, 327-345, 1993.

Texier, P.: Floods in Jakarta: when the extreme reveals daily structural constraints and mismanagement, Disaster Prevention and Management, 17, 358-372, 2008.

Viets, V. F.: Environmental and Economic Effects of Subsidence, Publication of Lawrence Berkeley National Laboratory, LBNL Paper LBL-8615, 251 pp., available at: http://escholarship.org/ uc/item/1sb4c8vh, last access: 20 October 2015, 2010.

Ward, P. J., Marfai, M. A., Yulianto, F., Hizbaron, D. R., and Aerts, J. C. J. H.: Coastal inundation and damage exposure estimation: a case study for Jakarta, Nat. Hazards, 56, 899-916, 2011.

Yong, R. N., Turcott, E., and Maathuis, H.: Groundwater extractioninduced land subsidence prediction: Bangkok and Jakarta case studies, Proceedings of the Fifth International Symposium on Land Subsidence, IAHS Publication no. 234, 89-97, 1995. 